\title{
Effect of osmotic suction on the stability of microaggregations and aggregations in a lateritic soil
}

\author{
Andrea Cardona Pérez $^{1 *}$, Ronaldo Vilela Wanderley Neto ${ }^{1}$, Rosemary Janneth Llanque Ayala and José Camapum \\ de Carvalho ${ }^{1}$
}

${ }^{1}$ Universidade de Brasília, postgraduate program in geotechnics, 70910-900 Darcy Ribeiro's Campus, Brasil

\begin{abstract}
It has been established that the matric suction is the portion of the total suction that affects, more directly, the mechanical behaviour of unsaturated soils, being less considered the effects of the osmotic suction. Considering that in the deeply weathered soils will occur, depending on its chemicalmineralogical characteristics, more or less ionic exchange between the soil particles and the chemical products to which the soil has been exposed to, the study of the osmotic suction and its impact on the soil textural and structural stability becomes relevant. In natural terrain and slopes, the chemical products come mostly from agricultural inputs, while in road constructions they come from additives such as lime and cement that are incorporated to the soil with the objective of enhancing its mechanical behaviour. In the case of cast in situ concrete foundations, part of the concrete's chemical compounds migrates to the surrounding soil. In all of the above mentioned cases, the matric suction acts on the chemical compounds' migration process, affecting soil's osmotic suction. Aiming at assessing the impacts of these chemical compounds on the soil properties and behaviour, soil-water characteristics curves of a lateritic soil mixed with a dolomitic limestone and a fertilizer were evaluated. The results show that, in the case of the fertilizer mixture, the variation of osmotic suction contributed to the disaggregation of the soil.
\end{abstract}

\section{Introduction}

Deeply weathered tropical soils stand out for presenting aggregations and microaggregations that interconnect through clay bridging and/or cements (iron and aluminium oxy-hidroxys) (Conciani et al. 2015 [1]). Depending on its chemical-mineralogical characteristics and on the presence of organic matter, these soils will present greater or lesser cation exchange capacity (CEC) (Raij 2010 [2], Ronquim 2010 [3]), making them more or less susceptible to changes on their composition after interacting with other chemical compounds.

These soils are also characterized by having a variable charge that depends on the environment $\mathrm{pH}$ (Tiecher 2015 [4]). When these soils absorb salts, particles' superficial charges are affected along the changes of the point of zero charge (PZC) (Marchi et al. 2006 [5]), condition that will interfere, for example, in the CEC. It is very difficult for an ionic exchange to be generated without affecting the structure of clay minerals due to the fact that these can decompose during the reactions (Grim 1962 [6]).

In the study of unsaturated soil, suction is one of the main phenomena to be considered, since it intervenes significantly in the mechanical behaviour of soils and alters itself due to variations in factors like porosity, moisture, degree of saturation and physical-chemical conditions of the soil and the environment.

The total suction $(\psi)$ corresponds to the sum of two portions: the matric suction (ua - uw) and the osmotic suction $(\pi)$. The first is considered as the one that directly affects the mechanical behaviour of unsaturated soils (Costa et al. 2003 [7], Elsharief et al. 2015 [8], Chen et al. 2019 [9]), since it is related with the type of the particles and with the structural arrangement of the soil (capillarity). On the other hand, the osmotic suction, that is directly related to the occurrence of concentration gradients of solutes in the interstitial water (Leong \& Abuel-Naga 2017 [10]), and its influence in the mechanical behaviour of the soil are usually less considered since changes in the chemical conditions of the soil and the environment are not frequent.

A way of relating suction to the content of water of a soil is through a soil-water characteristic curve (SWCC), that represents how the suction varies due to the gravimetric water content $(\mathrm{w})$ or volumetric water content $(\theta)$ or the degree of saturation (S). These curves can present different shapes because of the soil characteristics such as mineralogy, orientation of particles, void

* Andrea Cardona Pérez: andreita-29@,hotmail.com 
distributions and void ratio, among others features (Camapum de Carvalho \& Lerouil 2004 [11].

Another important concept to this study is the point of zero charge (PZC), or point of isoelectric charges, that corresponds to the $\mathrm{pH}$ value in which the liquid electrical charges of the particles is zero (Camapum de Carvalho et al. 2015 [12], [4]).

This paper aims to assess if the osmotic suction can intervene in the stability of aggregations and microaggregations present in lateritic soils when these soils interact with different chemical substances such as limes and fertilizers. The differences in the osmotic suction generated by these substances between the interior and exterior of tropical soil's aggregates and microaggregates, provide the migration of chemical elements and compounds to the interior of these aggregations and may enable its instability depending on the soil, on the characteristics of the chemical inputs and on the conditions to its migration.

Moreover, experimental evidences of the chemical products migration to the soil are presented for the case of a cast in situ concrete pile and a soil stabilized with lime, attesting that the consequences related to this phenomenon are relevant in the context of civil engineering. The obtained result set highlights the need of broader studies about the influence of osmotic suction upon the behaviour of deeply weathered tropical soils.

\section{Methodology}

The disturbed soil samples used in this study were obtained at the depth of $1 \mathrm{~m}$ and correspond to a lateritic soil that composes a tropical weathering profile (Pastore \& Fontes 1998 [13]). According to the Unified Soil Classification System (USCS), it is a clay silt of low plasticity (Burgos 2016 [14]). This soil was mixed with a Dolomitic Limestone (DL), a substance widely employed as a soil acidity regulator and conditioner, and a compound denominated as SUC, which was obtained by mixing, in equal amounts, the following fertilizers: Single Superphosphate, Urea and Potassium Chloride.

SWCC of total and matric suction were determined through the filter paper method to evaluate if the chemical transfer between the soil and these substances intervene on the osmotic suction. Also, considering these SWCC and the results of the granulometric distribution for each mixture (Pérez 2018 [15]), the impact of osmotic suction variations on the stability of aggregates and microaggregates is analysed.

Regarding the suction test, 14 specimens were prepared for each SWCC determination. These 14 test points represent a variation of the degree of saturation between $5 \%$ and $100 \%$. The mixture preparation was done following these steps: firstly, the soil in its natural moisture condition was air-dried until a loss of $1 \%$ in its gravimetric water content. Posteriorly, the DL and the SUC were separately diluted in water, being that the employed chemical substance mass was $10 \%$ of the moist soil mass. The utilized amount of water was equivalent to the mass of evaporated water in the previous step. This solution was then mixed with the soil until a visually homogeneous mixture was obtained. Afterwards, a dynamic compaction was done applying 6 blows with the light rammer utilized in the mini MCV compaction method, resulting in cylindrical specimens of approximately $2,5 \mathrm{~cm}$ high and $5 \mathrm{~cm}$ in diameter. To obtain this specific height, $100 \mathrm{~g}$ of soil was employed.

Once all the specimens were compacted, the control of the degree of saturation was done through the weighting of the specimens, in order to know how much water to add or remove from the specimens so they reached the preestablished degrees of saturation. When these degrees of saturation were achieved, the test was assembled according to ASTM D5298 (2016) [16]. It is worth mentioning that, for the same specimen, both matric and total suction were determined so the osmotic suction could also be obtained by the difference of the first two. Figure 1 illustrates the assembled test.

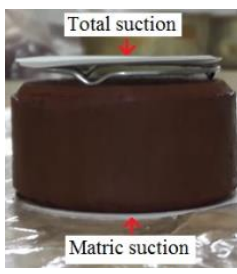

a)

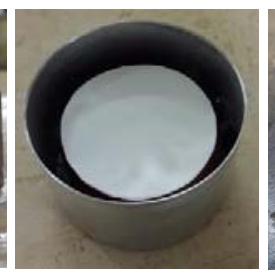

b)

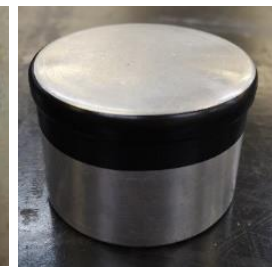

c)
Fig. 1 a) Filter papers positioned on the specimen; b) specimen with filter papers inside capsule; c) sealed capsuled.

Once sealed, the capsules were put inside a sealed styrofoam box to avoid external temperature and humidity variations as much as possible. The box was kept in a climatized chamber for a 10 days period to ensure that the soil-papers sets reached equilibrium.

After all the above-mentioned process, the granulometric distributions of the soils after interacting with the chemical substances were determined following the NBR 7181 (2016) [17], except for the use of the soil stirrer and the deflocculant since the employment of these techniques could affect the studied aggregations and microaggregations. The same granulometric analysis was utilized for the soil that did not interact with chemical substances.

Then, once the SWCC was obtained, it was possible to evaluate if the transfer and interaction of these chemical substances with the soil affected the osmotic suction values. In addition, allying these SWCC with the granulometric distributions, made it possible to assess the influence of the osmotic suction on the stability of aggregates and microaggregates of the soil.

Apart from the process performed with the specimens in laboratory conditions, an element representing the top part of a concrete pile was casted on the field, close to the spot where the soil samples were obtained. Through $\mathrm{pH}$, electrical conductivity and granulometric distributions tests, the study sought to attest the transfer of chemical compounds from the concrete to the surrounding soil and evaluate the possible effects of these chemicals on the soil texture.

After digging a borehole $75 \mathrm{~cm}$ deep and $15 \mathrm{~cm}$ in diameter, it was filled with a fresh concrete mixture typically employed in continuous helical piles throughout the region (Wanderley Neto 2020 [18]), with a trace of 
1:1,079:1,079:2,019 (high early strength cement, natural sand, crushed sand, gravel $\mathrm{D}_{\text {máx }}=12,5 \mathrm{~mm}$ ) and water cement ratio of 0,543 . After a 50 days period, $360 \mathrm{~cm}$ deep boreholes were dug at varying distances from the pile and disturbed soil samples were collected in two different points at the bottom of each borehole (Figure 2).

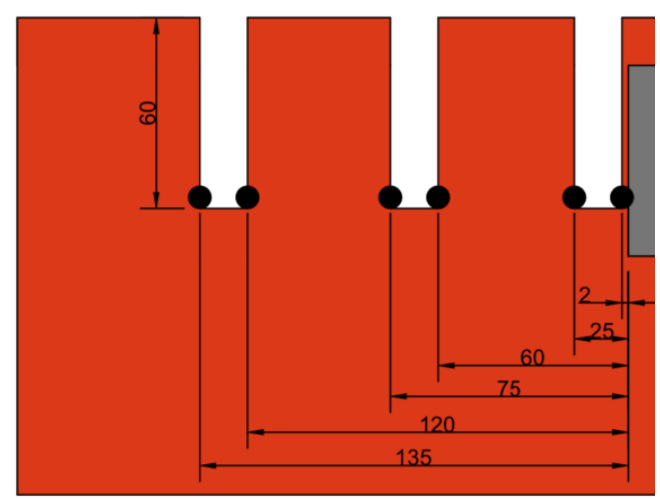

Fig. 2. Boreholes dug near the concrete pile and sampling points (dimension lines in $\mathrm{cm}$ )

With the collected soil, $\mathrm{pH}$ tests were carried out following EMBRAPA (2018) [19], except for the manual crushing and drying, since it was decided to keep the soil as much close to the field condition as possible. The electrical conductivity was determined by an electrical conductivity meter coupled to the digital $\mathrm{pH}$ meter (AKSO AK59), utilizing the same soil-water solution evaluated in the $\mathrm{pH}$ tests. At last, granulometric distribution tests were performed following [17] for the samples taken at the closest point from the pile $(2 \mathrm{~cm})$ and at the point distanced $60 \mathrm{~cm}$.

\section{Results}

In Figures 3, 4 and 5 are presented, respectively, the matric, total and osmotic suction SWCC in function of w, for the natural lateritic soil and the soil-DL and the soilSUC mixtures.

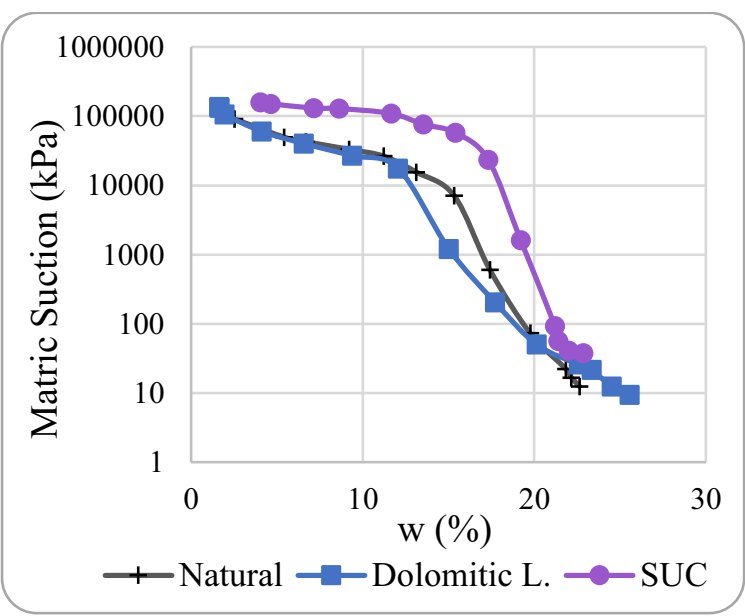

Fig. 3. Matric suction SWCC of natural soil and mixtures.

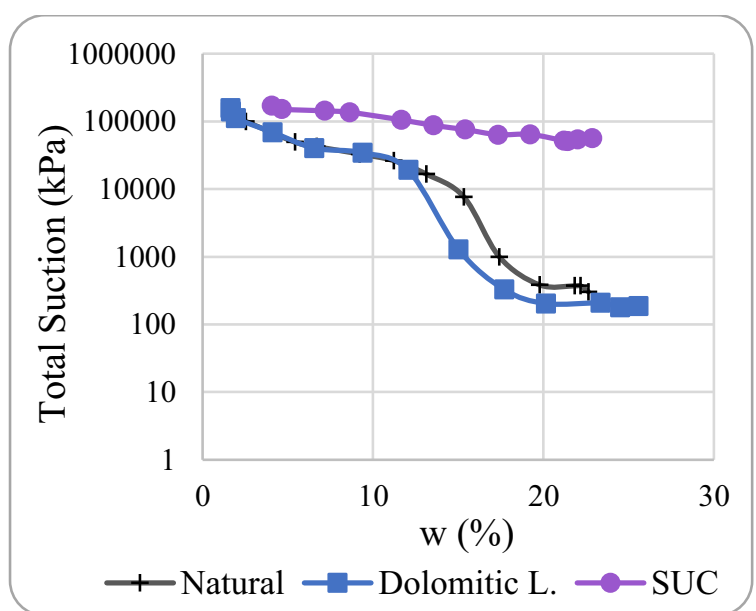

Fig. 4. Total suction SWCC of natural soil and mixtures

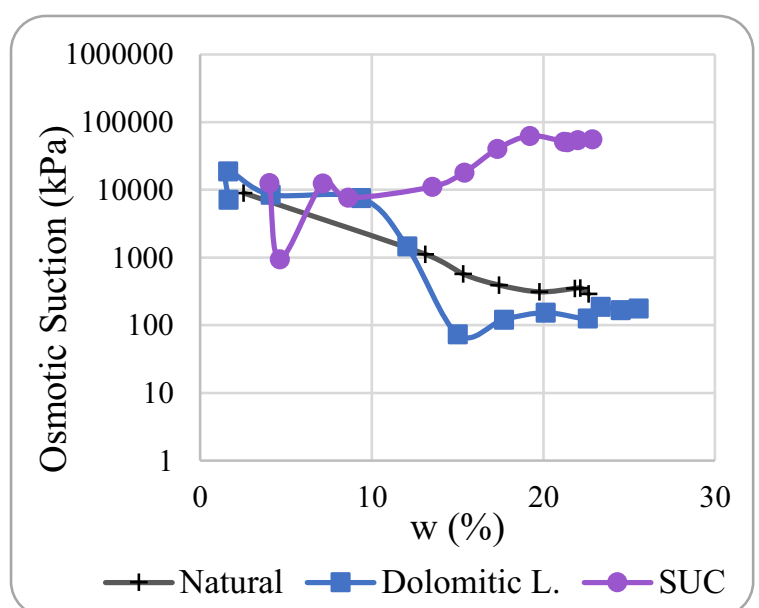

Fig. 5. Osmotic suction SWCC of natural soil and mixtures.

It is observed in Figure 3 that the matric suction values of the soil-DL mixture were similar to those from the natural soil, indicating there were no significant changes in this property during the interaction between the added chemical compound and the soil. Analysing the granulometric distribution (Figure 6) it is verified that both the natural soil and the soil-DL mixture have the same granulometry. In turn, the effect unleashed by the SUC fertilizer was the increase in matric suction values throughout the whole SWCC. This observation is attributed to a decrease in the size of soil pores, arising from a disaggregation caused by the interaction with the fertilizer that can be seen in Figure 6 . 


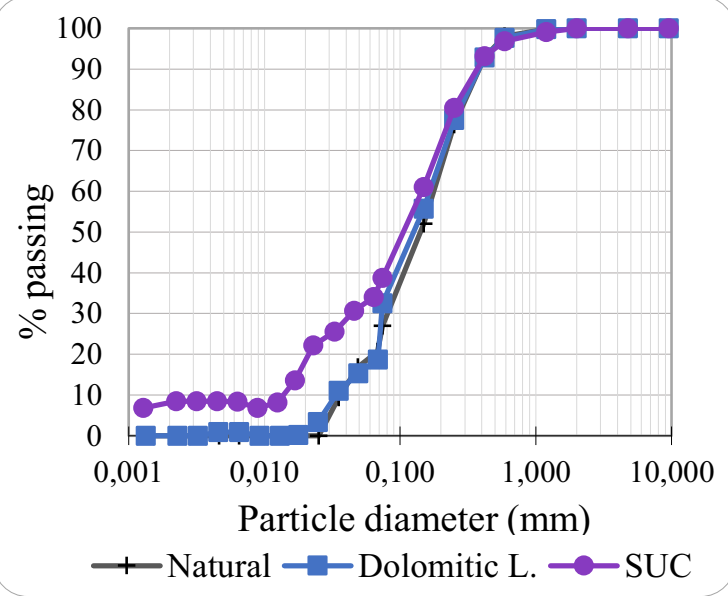

Fig. 6. Granulometric distribution of natural soil and mixtures. From: [15].

Evaluating the results shown in Figure 4, it is observed that the total suction values in the meso and macropores zone increased significantly for the case of the soil-SUC mixture, indicating a great effect of this fertilizer on the osmotic suction. This effect is due to the large amount of salts that migrates from the fertilizer to the soil and, as these salts react with the clay minerals of the soil and dissolve in the available water, they prevent water molecules from evaporating. Thusly, the vapor pressure decreases and, consequently, the osmotic suction increases (Fredlund \& Rahardjo 1993 [20]), resulting in an increment of the total suction values.

What was mentioned in the previous paragraph can be better observed in Figure 5, in which are presented the osmotic suction SWCC in function of w. For both the natural soil and the soil-DL mixture, the osmotic suction decreases with the increase in $\mathrm{w}$, fact that corroborates the expected behaviour for soils. On the other hand, the soilSUC mixture presented an increase in the osmotic suction values when compared to the natural soil. It is perceived that the difference between the osmotic suction of the soilSUC mixture and the natural soil is greater as the water content increases, that is, as the zone in which the suction acts passes from the micropores zone to the meso and macropores zone.

It is worth mentioning that the meso and micropores zones are where the salts concentrate the most and, consequentely, the osmotic suction SWCC for the soilSUC mixture in this region is visually shifted upwards. In turn, the effect of the fertilizer on the osmotic suction in the micropore zone is small, mainly for water contents below the micropores air entry values. In terms of hypothesis, in this zone the air present inside the aggregates and microaggregates tends to remain trapped, preventing the entry of fluids containing chemical compounds and thereby retarding the alteration of the osmotic suction and making its impact on this zone of the SWCC not to stand out.

From Pérez (2018) [15], it is known that the $\mathrm{pH}$ of the soil-SUC mixture, the natural soil and the soil-DL mixture are, respectively, 5.5, 6.1 and 8 , while the $\mathrm{pH}$ corresponding to the PZC of the natural soil is 5.7. This means that the addition of SUC induces the mixture to pass through the soil's PZC. According to observations made by Rezende (2003) [21], when the $\mathrm{pH}$ of a soil mixed with a chemical substance is near the soil's PZC, this soil undergoes through a disaggregating effect, fact observed in the present study for the soil-SUC mixture. Therefore, considering the great amount of salts provided by the SUC compound (Fig. 5), its dissaggregating effect (Fig. 6) and the changes caused by this fertilizer in the $\mathrm{pH}$ of the soil (arising from chemical reactions), it is assessed that the osmotic suction possibily contributes to unstabilize aggregations and microaggregations. In the case of the soil-DL mixture, due to the low supply of salts to the soil, the osmotic suction is not submitted to great alterations neither is the stability of its aggregations and microaggregations affected. Nevertheless, more specific tests are needed to confirm these analyses.

For the purpose of complementing this study and pointing out the importance of the topic in civil engineering, it is also exposed results from tests carried out with the surrounding soil of a casted in situ concrete pile. In Figure 7 are presented $\mathrm{pH}$ results obtained from soil-distilled water solutions utilizing soil from each sampling point (Fig. 2). It is observed that, differently from what was noted in other sampling boreholes, in the nearest borehole the two sampling points presented a large difference between the $\mathrm{pH}$ values, (soil distanced $2 \mathrm{~cm}$ from pile: $\mathrm{pH}=8.4$; soil distanced $25 \mathrm{~cm}$ from pile: $\mathrm{pH}=$ 7.6). Thus, it was verified a soil alkalinization insofar as the sample was closer to the concrete.

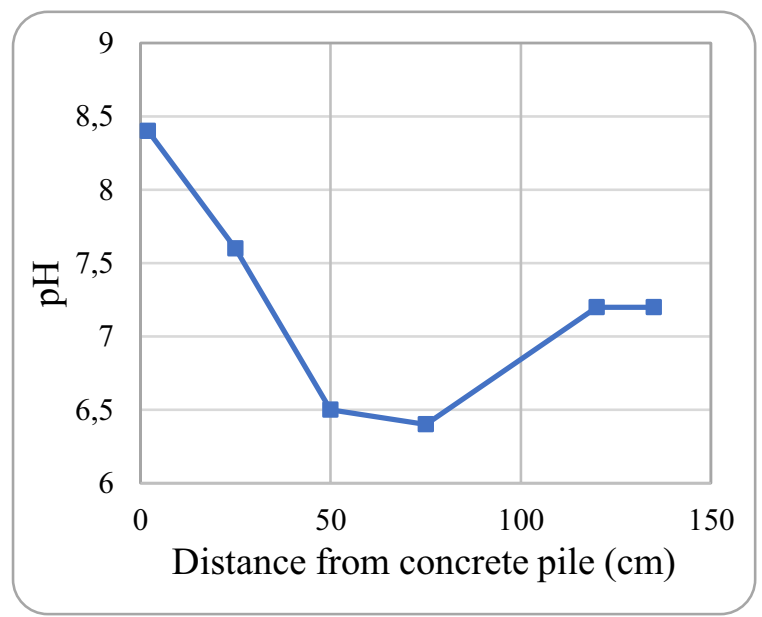

Fig. 7. Soil $\mathrm{pH}$ (horizontally distanced from pile and at a depth between $50 \mathrm{~cm}$ and $60 \mathrm{~cm}$ )

Besides this alkalinization indicative, it is also presented results of soil electrical conductivity tests for the same studied sampling locations (Fig. 8). The natural soil has an electrical conductivity equal to $27 \mu \mathrm{S} / \mathrm{cm}$. It turns out that the closest soil from the pile had its electrical conductivity significantly increased to the value of 277 $\mu \mathrm{S} / \mathrm{cm}$. The soil in the other sampling points presented electrical conductivity values in the same range as the natural soil, varying between $38 \mu \mathrm{S} / \mathrm{cm}$ (soil distanced $135 \mathrm{~cm}$ from pile) and $15 \mu \mathrm{S} / \mathrm{cm}$ (soil distanced $75 \mathrm{~cm}$ from pile). So, these results, along with the $\mathrm{pH}$ ones, confirmed that a migration of chemical compounds from the concrete pile to the surrounding soil exists. This verification is important since the mentioned chemical 
compounds may alter the osmotic suction and structural stability of the soil.

In principle, since the studied soil $\mathrm{pH}$ is greater than its PZC (5.7), its increment would not result in a disaggregating effect since the $\mathrm{pH}$ did not pass through the PZC value of this lateritic soil. However, being that the aggregates present in this soil are usually rich in iron and aluminium oxy-hydroxys (fact that grants their stability), it is necessary to separately consider the PZC for each of these compounds. Spósito (1984, apud Farias, 2012 [22]), presents, respectively, for the PZC of goethite and hematite the values of 7.3 and 8.5 , determined by potentiometric titration. Prado (2003) [23] presents, for kolinite, PCZ equal to 4.6 and, for gibbsite, 5.1. Consequently, the increment in $\mathrm{pH}$ values could favour disaggregation in lateritic soil, mainly acting upon goethite and hematite.

With respect to the soil structure, evaluated through granulometric distribution tests, the results point to a disaggregating effect in the closest zone to the concrete (Fig. 9) acting in the aggregates coarser fraction, since the silt and clay content remained practically constant. In Figure 9, it is verified that, while in the soil distanced 60 $\mathrm{cm}$ from the concrete pile the mass percentage passing through sieve $\# 200$ is $20 \%$, for the soil distanced $2 \mathrm{~cm}$ this percentage is equal to $31 \%$.

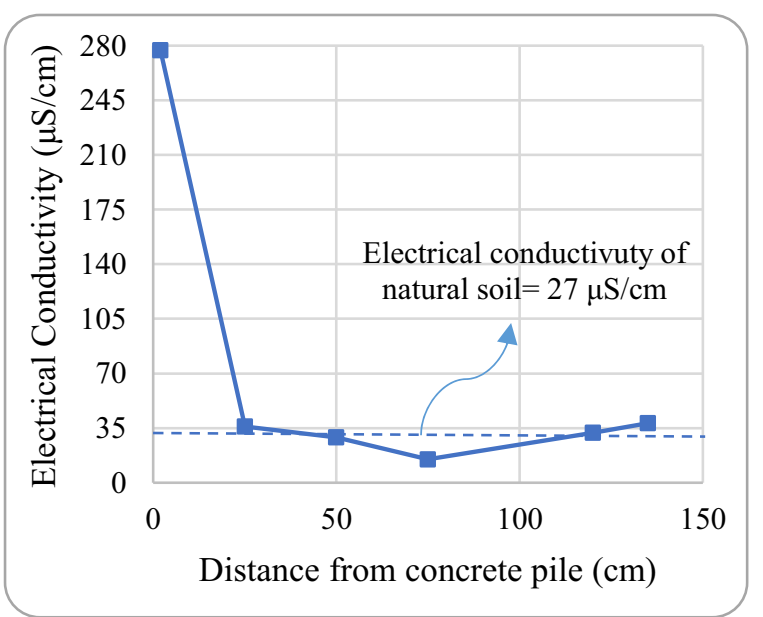

Fig. 8. Electrical conductivity of soil horizontally distanced from pile

Following the same line of thought adopted in the analysis of the soil-SUC and soil-DL mixtures, the chemical changes observed in the soil near the concrete pile (Fig. 7 and 8), derived precisely from the migration of chemical compounds, among them salts, from the pile to the surrounding soil, certainly influence the osmotic suction of this soil. At the same time, it is observed a disaggregating effect happening in the soil close to the concrete, being this fact possibly related to the variation of osmotic suction and relevant for the soil-concrete interface strength. It is emphasized that the determination of the SWCC for the soil in this condition is needed to confirm this hypothesis and is currently being done by the authors.

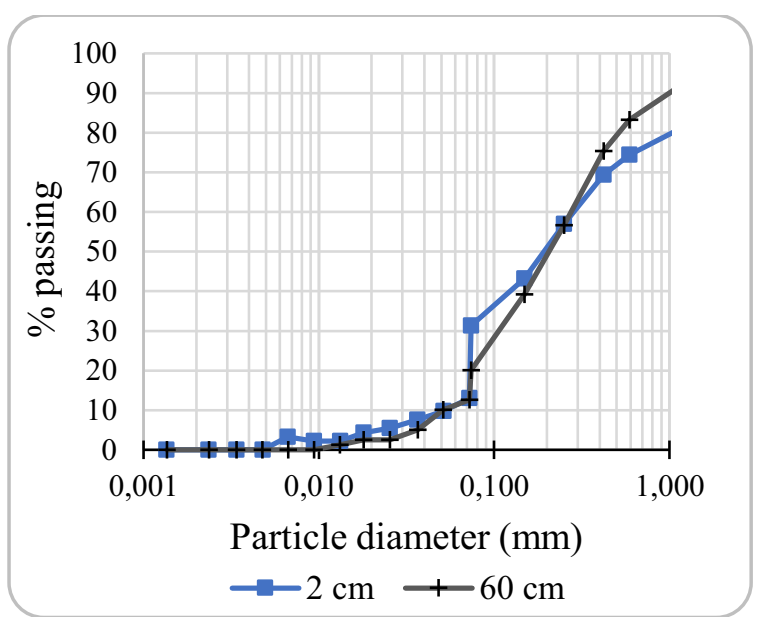

Fig. 9. Soil granulometric distribution after 50 days curing period (sampling points distanced $2 \mathrm{~cm}$ and $60 \mathrm{~cm}$ from concrete pile)

It has to be taken into consideration that, in the case of the analysed concrete, the chemical migration occurs, at first, by the action of matric suction. As for at the moment of the pile concreting, the matric suction of the concrete is null (fresh concrete) and the same property of the soil is greater than zero, since it is in an unsaturated condition. This matric suction gradient enables the flow.

Moreover, in order to highlight the importance of suction in the migration of chemical compounds added to soil mixtures, and emphasize that these compounds can make the soil unstable - pointing out that the osmotic suction deserves more attention - in Figures 10 and 11 are presented results arising from granulometric distributions tests performed in a natural soil and in this same soil stabilized with type CH-III hydrated lime (addition of $4 \%$ of the mass of dry soil) (Ayala 2020 [24]), called soil-lime mixture from now on. The analysed soil was collected at a depth of $2 \mathrm{~m}$ in the same location as the rest of the samples presented so far. The natural soil as well as the stabilized were compacted with the same amount of energy and tested after a 1-day curing period. Afterwards, the specimens were buried in a $50 \mathrm{~cm}$ deep ditch, all together, and kept in this condition for a whole year. Once this curing period was over, the specimens were then tested again.

The Figure 10 presents the granulometric distributions determined for the natural soil, both with and without the use of deflocculant (CD and SD, respectively), and for the soil-lime mixture after a 1-day curing period. It is observed that, after this brief period, the lime has little influence on the textural stability of the soil.

In Figure 11 are presented granulometric distributions for the natural soil, without the use of deflocculant, determined before burying and after 1 year being buried, as well as the results for the soil-lime mixture also after the 1-year curing period (buried) that the samples were imposed to. It becomes clear the disaggregating effect of lime and the fact that part of its chemicals migrated to the natural soil. In both cases, it is understood that the osmotic suction played a role in the migration of chemical compounds responsible for unstabilizing aggregations.

Both the surrounding soil of the concrete pile and the soil-lime mixture investigations indicate a necessity of 
more studies about the importance of osmotic suction when foreign chemical compounds are introduced to the soil.

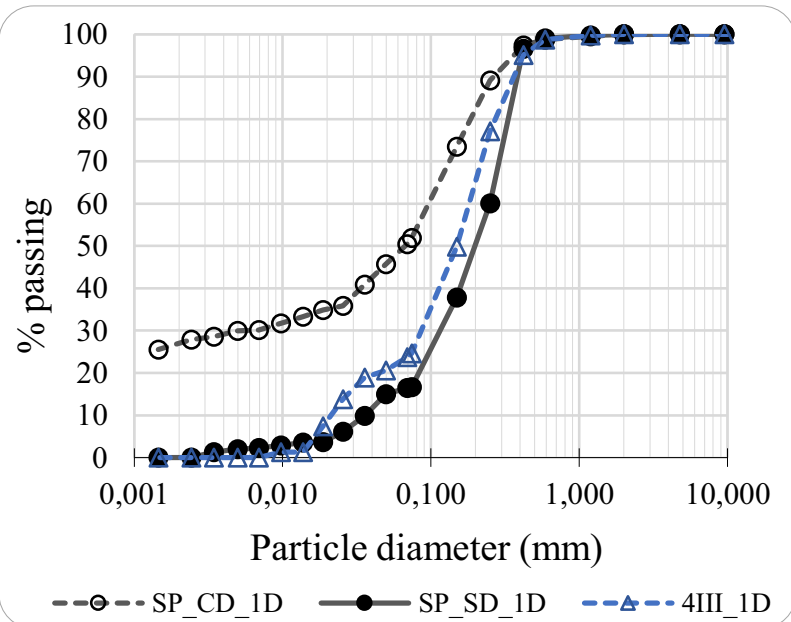

Fig. 10. Influence of lime in soil granulometry (1-day curing period)

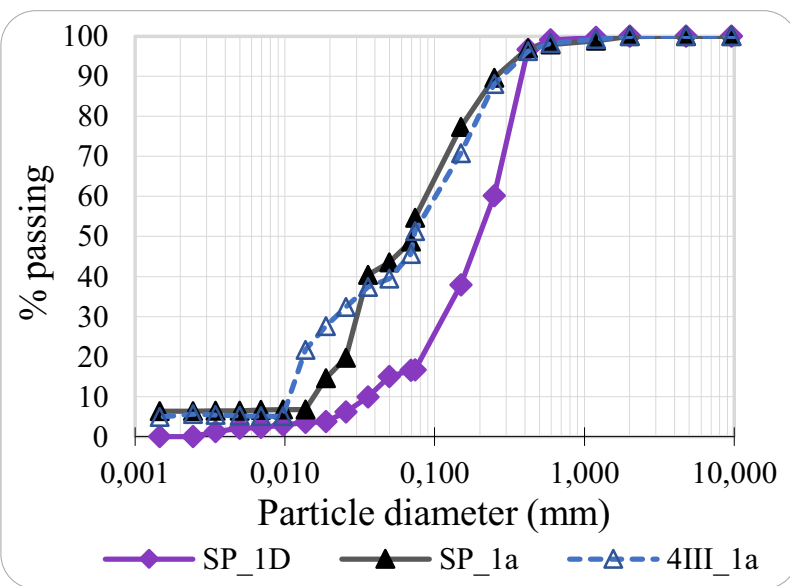

Fig. 11. Influence of lime in soil granulometry (1-year curing period)

\section{Conclusions}

It was observed that the osmotic suction and its effects vary depending on the chemicals added to the soil. In the case of the soil-DL mixture, values of osmotic suction do not considerably vary and do not affect the stability of aggregates and microaggregates. Conversely, for the case of the soil-SUC mixture (compound that provides a large amount of salts to the soil), the osmotic suction values suffer great variation. Allying these results with the ones from $\mathrm{pH}$ and granulometric distributions tests, it was established the possibility that osmotic suction can affect, mainly, the stability of aggregations and, to a smaller degree or even no degree at all, the microaggregations.

In the analysis made for the soil surrounding the concrete pile, it was confirmed the migration of chemical compounds from the concrete to the soil and it was observed a possible disaggregating effect of these chemicals on the soil very close to the concrete. Since these chemical compounds from the concrete are largely salts, a variation of osmotic suction at the soil-concrete interface certainly occurs. This fact may imply a change in stability conditions for the studied lateritic soil.

The investigations carried out on the soil-lime mixture corroborate the results obtained for the soil-SUC mixture and reinforce the importance of more studies aimed at assessing the impact of osmotic suction upon tropical soils properties and behaviour.

\section{REFERENCES}

1. W. Conciani, P. C. Burgos, R. L. Bezerra. (2015). Solos não saturados no contexto geotécnico. Cap. 2, Origem e formação dos solos, perfis de intemperismo. ABMS. 21-37.

2. B. V. Raij. (2010). Fertilidade do solo no Brasil: contribuições do Instituto Agronômico de Campinas. IPNI. 1-13.

3. C. C. Ronquim. (2010). Conceitos de fertilidade do solo e manejo adequado para regiões tropicais. EMBRAPA - Boletim de Pesquisa e Desenvolvimento. 8, 1-26.

4. T. A. Tiecher. (2015). A química antes da química do solo. 94.

5. G. Marchi, L. R. G. Guilherme, A. C. Chang, N. Curi, M. C. Guerreiro. (2006). Changes in isoelectric point as affected by anion adsorption on two brazilian oxisols. Comm Soil Sci Plant Anal. 37, 1357-1366, doi: 10.1080/00103620600626833.

6. R. Grim. (1962). Applied Clay Mineralogy. 422.

7. Y. D. Costa, J. C. Cintra, J. G. Zornberg. (2003). Influence of matric suction on the results of plate load test performed on a lateritic soil deposit. GTJ. 26, 10, doi: 10.1520/GTJ11326J.

8. A. M. Elsharief, O. A. Abdelaziz, M. A. Dafallaa. (2015). The influence of matric suction on the shear strength of highly plastic compacted swelling clays. EJGE. 20, 12555-12568.

9. W. B. Chen, W. Q. Feng, L. Borana, J. H. Yin. (2019). Influence of matric suction on nonlinear timedependent compression behaviour of a granular fill material. Acta Geotechnica. 15, 615-633, doi: 10.1007/s11440-018-00761-y.

10. E. C. Leong \& H. Abuel-Naga. (2017). Contribution of osmotic suction to shear strength of unsaturated high plasticity silty soil. Geomech energy environ. 15, 65-73, doi: 10.1016/j.gete.2017.11.002.

11. J. Camapum de Carvalho \& S. Leroueil. (2004). Curva característica de sucção transformada. Solos e rochas. 27, 231-242.

12. J. Camapum de Carvalho, G. de F.N. Gitirana, S. L. Machado, M. M. dos A. Mascarenha, F. da S. Chagas. (2015). Solos não saturados no contexto geotécnico. ABMS. 805.

13. E. L. Pastore \& R. M. Fontes. (1998). Geologia de Engenharia, Caracterização e classificação de solos. 197-210. 
14. J. F. Burgos. (2016). Influência da microestrutura no comportamento mecânico dos solos tropicais naturais e compactados. UnB. 149, G.DM-272/16.

15. A. C. Pérez. (2018). Influência de insumos agrícolas em propriedades físicas de solos tropicais. UnB. 103, G.DM-298/18

16. ASTM D5298-16. (2016). Standard test method for measurement of soil potential (suction) using filter paper. 6.

17. NBR 7181. (2016). Solo - Análise granulométrica. ABNT. 12.

18. R. V. Wanderley Neto. (2020). Estudo experimental de interfaces solo-concreto no contexto de solos não saturados. UnB. 206, G.DM - 344/2020.

19. EMBRAPA. (2018). Manual de métodos de análise de solo. 963.

20. D. G. Fredlund \& H. Rahardjo. (1993). Soil mechanics for unsaturated soils. 82-85.

21. L. R. Rezende. (2003). Estudo do comportamento de materiais alternativos utilizados em estruturas de pavimentos flexiveis. UnB. 372, G.TD-014A/03.

22. W. M. Farias. (2012). Processos Evolutivos de Intemperismo Químico e sua Ação no Comportamento Hidromecânico de Solos do Planalto Central. UnB. 284, G.TD-077A/2012.

23. R. M. Prado. (2003). A calagem e as propriedades físicas de solos tropicais: revisão de literatura. Revista Biociências. 9, 7-16.

24. R. J. L. Ayala. (2020). Melhoria de Solos com Fibras Provenientes da Indústria Avícola. UnB. 300, G.TD159/2020. 